\title{
Poor knowledge of anemia and sexually transmitted disease but better knowledge of HIV/AIDS among unmarried adolescents aged 15-24 years
}

\author{
Edhyana Sahiratmadja ${ }^{1 *}$, Mugia Bayu Raharja ${ }^{2}$, Elsa Pudji Setiawati ${ }^{3}$, \\ and Ramdan Panigoro ${ }^{1}$
}

\begin{abstract}
\section{BACKGROUND}

Basic knowledge of sexual and reproductive health is important to be introduced during the premarital period, to reduce high-risk sexual behavior among adolescents, as well as to increase the correct attitude in their future marriage. This study explored the knowledge of HIV/AIDS, sexually transmitted diseases (STDs) and anemia among unmarried adolescents.
\end{abstract}

\section{METHODS}

This was a cross-sectional analytical study on secondary data from the Indonesian Demographic and Health Population Survey 2017, initially conducted by the National Population and Family Planning Board $(B K K B N)$. Knowledge of HIV/AIDS, STDs and anemia among unmarried adolescents aged 15-24 years in West Java Province and Jakarta, the capital city of Indonesia, was compared and analyzed using the chi-square test.

\section{RESULTS}

In total 5,389 weighted data were retrieved. In general, adolescents in Jakarta had better knowledge of all diseases compared to those in West Java $(p<0.001)$. Knowledge of anemia and STDs was poor compared to that of HIV/AIDS which was moderate to good $(\mathrm{p}<0.001)$. Interestingly, although the adolescents had a middle-low wealth index $(43 \%)$, the majority $(>90 \%)$ had their own mobile phone with almost daily internet access, however most of their information sources on health education were from their school period.

\section{CONCLUSION}

Premarital education in schools is imperative to enhance the knowledge of STDs and anemia. Moreover, poor knowledge of anemia is a challenge for introducing the topic of thalassemia major, an inherited autosomal recessive type of anemia due to hemoglobinopathy. Since Indonesia is harboring 6$10 \%$ of thalassemia carriers, integrative premarital education is needed for better family planning.

Keywords: Iron deficiency anemia, Indonesian Demographic and Health Survey, premarital, thalassemia carrier, thalassemia major
${ }^{1}$ Department of Biomedical Sciences, Faculty of Medicine, Universitas Padjadjaran, Bandung, Indonesia ${ }^{2}$ BKKBN, National Population and Family Planning Board - Population Research and Development Unit, Jakarta, Indonesia

${ }^{3}$ Deparment of Public Health, Faculty of Medicine, Universitas Padjadjaran, Bandung, Indonesia

*Correspondence:

Edhyana Sahiratmadja

Department of Biomedical Sciences,

Faculty of Medicine,

Universitas Padjadjaran

Jl. Raya Sumedang Km 21 Jatinangor, Bandung, Indonesia

E-mail: e.sahiratmadja@unpad.ac.id, Phone: +62-816-996309

ORCID ID : 0000-0001-9092-5848

Date of first submission, March 24, 2021

Date of final revised submission, July 9, 2021

Date of acceptance, July 13, 2021

This open access article is distributed under a Creative Commons Attribution-Non Commercial-Share Alike 4.0 International License

Cite this article as: Sahiratmadja E, Raharja MB, Setiawati EP, Panigoro R. Poor knowledge of anemia and sexually transmitted disease but better knowledge of HIV/AIDS among unmarried adolescents aged 15-24 years. Univ Med 2021;40:107-17. doi: 10.18051/ UnivMed.2021.v40.110-120 


\section{INTRODUCTION}

Sexual and reproductive health account for a high proportion of global public health problems. The basic knowledge of various sexually transmitted infections and HIV/AIDS as well as of reproductive health is important to be introduced to adolescents during the premarital period to reduce high-risk sexual behavior. $^{(1)}$ The incidence of AIDS cases in Indonesia has been reported to be highest at the age of 25-49 years. ${ }^{(2)}$ Therefore, adolescents and young adults are the age groups with the highest risk of contracting HIV infection possibly due to poor knowledge regarding HIV/ AIDS. Furthermore, HIV/AIDS is closely related to sexual transmitted infections. Good knowledge of HIV/ADIS and sexually transmitted diseases (STDs) may increase good attitude in their future marriage, as well as eliminate the three infections in mother-to-child transmission, consisting of HIV/AIDS, syphilis and hepatitis B. ${ }^{(3)}$

Another disease that adolescents need to know is anemia, that affects about $40 \%$ of children under 5 years of age and $30 \%$ of nonpregnant women. ${ }^{(4)}$ The risk factors of anemia are multifactorial, including chronic infections and inflammation, micronutrient and macronutrient deficiencies, with iron deficiency as the major cause. ${ }^{(5)}$ Anemia may lead to impaired cognitive performance, poor educational achievement, resulting in reduced work capacity. Especially in young women, anemia may have impacts on their future pregnancies, among others poor pregnancy outcomes and increased maternal and perinatal mortality and morbidity. Furthermore, anemic pregnant women have a higher risk during the pregnancy, both for the mother and the fetus, leading to intrauterine growth retardation or preterm delivery. ${ }^{(6)}$ Moreover, anemia in children is becoming a public health issue that may contribute to stunted growth and an increased susceptibility to infections. Although the prevalence of iron deficiency anemia (IDA) due to malnutrition in adolescents is high in the developing countries, ${ }^{(7)}$ IDA is not the only major cause in adolescents. Since Indonesia is located in the thalassemia belt area, hemoglobinopathies such as thalassemia, an inherited autosomal recessive anemia, are also prevalent. ${ }^{(8)}$ Good awareness of thalassemia carrier status is important in the premarital phase, as this knowledge is needed for better family planning. Adolescence is a unique point of intervention as this age group is more receptive to changes in lifestyle that may determine their life course later. ${ }^{(9)}$

A study in Berlin showed that students had heard of HIV, and the majority rated their knowledge as (rather) good and knew that HIV could neither be cured nor vaccinated against. ${ }^{(10)}$ Another study showed different results, knowledge about some aspects of HIV and other STDs was inadequate among both science and non-science high school and university students. ${ }^{(11)}$

This study aimed to assess the knowledge of HIV/AIDS, STDs and anemia among unmarried adolescents aged 15-24 years residing in West Java and Jakarta, the capital city of Indonesia, as a reference.

\section{METHODS}

\section{Study Design}

This was a cross-sectional study, using secondary data, partly retrieved from the Indonesian Demographic and Health Survey (IDHS) for 2017 [Survei Demografi dan Kesehatan Indonesia (SDKI) 2017]. ${ }^{(12)}$

\section{Research subjects}

The IDHS 2017 sample was a geographically stratified and clustered sample of households, with a number of respondents representing the population of the provinces. The inclusion criterion was all unmarried men and women aged 15-24 years in the selected clustered area who agreed to participate. The samples were weighted to inflate the sample 
data, either from a small province or a large province, to be equivalent to the size of the total national population. In brief, two-stage sampling was designed. The sample size of Population Census 2010 was calculated based on systematic probability proportional to size, resulting in 1,970 census blocks of urban and rural areas. Of each census block, 25 families or households were chosen systematically.

The current study had retrieved a total of data ( $\mathrm{n}=5,389$; weighted) from two provinces, namely from DKI Jakarta, the capital city of Indonesia, where a premarital health examination and education program had been made mandatory, ${ }^{(13)}$ and from West Java, the largest province in Indonesia, harboring the majority of thalassemia major patients. ${ }^{(8)}$

\section{Indonesian demographic and health survey 2017 questionnaires}

There were two sets of questionnaires namely for reproductive women aged 15-49 years (SDKI 17-WUS), and for men aged 1524 years (SDKI 17-RP). The structured questionnaires were distributed to the respondents by direct interviews by cadres, conducted from July to September 2017. Data of unmarried men and women aged 15 to 24 years were retrieved, and questions related to knowledge of HIV/AIDS, sexually transmitted diseases (STDs) and anemia were explored and compared between the two provinces.

The wealth index was computed as a composite index using principal components analyses of various variables, including ownership of various assets, access to electricity, and other parameters related to source of drinking water and sanitation facilities and categorized as very poor, poor, middle, rich or very rich classes..$^{(12,14)}$

The questionnaire about HIV/AIDS consisted of ten closed questions (Q1002 to Q1008C) and knowledge was categorized as good (score 810), moderate (score 5-7) and poor (score d" 4). The questionnaire about STDs consisted of three open questions (Q1042 B, C, D), and the questionnaire about anemia consisted of five questions of which two were closed questions (Q 1313) about whether the respondents had ever heard of anemia and (Q1316) whether anemia was treatable; and three open questions about the definition (Q1314), etiology (Q1315) and prevention or treatment of anemia (Q1317). For the open questions, the respondents were allowed to answer to the extent of their knowledge. For each correct answer the given score was one. Knowledge of anemia and STDs was categorized as good (score $\geq 10$ ), moderate (score 5-9) and poor score $\leq 4$ ).

\section{Statistical analyses}

Sampling weights were applied to all analyses. The analysis consisted of two steps; first, a descriptive analysis to explore the distribution of variables such as "ever heard of" diseases and definition. The distribution was reported as percentages. Second, the associations between place of residence and knowledge of HIV/AIDS, STDs or anemia were analyzed using the chi-squared test. Results were considered significant when $\mathrm{p}<0.05$.

\section{Ethical clearance}

Ethical clearance for the initial survey had been granted in the Institutional Review Board Findings Form (ICF IRB FWA00000845) for ICF Project no. 132989.0.000 for the year 2015. For using the secondary IDHS 2017 data, no separate ethics approval was required, except the permission from the National Population and Family Planning Board, Indonesia.

\section{RESULTS}

\section{Characteristic of unmarried adolescents} and young adults in Jakarta and West Java

Of 5,389 weighted data retrieved, $19.8 \%$ of the respondents was from the capital city of Jakarta and 80.2\% from West Java, the latter residing predominantly in urban areas $(71.9 \%)$. The respondents comprised 55\% men and $45 \%$ women, with the proportion of adolescents aged 
15-19 years being slightly higher (54\%) (Table $1)$. The wealth index in urban areas of Jakarta and West Java was upper middle class, whereas in rural areas of West Java the index was lower middle class. Interestingly, the mobile phone has become an essential tool in this era of digitalization, with more than $90 \%$ of the respondents having a mobile phone. Moreover, over $90 \%$ had internet access and in $80 \%$ the frequency of usage in the previous month was almost daily (Table 1).

\section{Knowledge about anemia compared to STDs and HIV/AIDS}

The majority of adolescents in Jakarta $(82 \%)$, West Java urban area $(70 \%)$ and rural area $(60 \%)$ admitted that they had 'ever' heard about anemia. Adolescents from Jakarta had significantly heard more than had those from West Java ( $p=0.000)$; moreover, adolescents in urban areas of West Java had heard more than had those in rural areas (p 0.000) as depicted in Figure 1.

Table 1. Characteristics of unmarried adolescents and young adults from the capital city DKI Jakarta and West Java Province based on urban and rural area

\begin{tabular}{|c|c|c|c|c|c|}
\hline \multirow[b]{2}{*}{ Characteristic } & \multirow{2}{*}{$\begin{array}{l}\text { Jakarta } \\
\text { n (1065) }\end{array}$} & \multicolumn{2}{|c|}{ West Java Province } & \multirow{2}{*}{$\begin{array}{c}\text { Total } \\
\mathbf{n} \\
(\mathbf{5 3 8 9})\end{array}$} & \multirow[b]{2}{*}{$(\%)$} \\
\hline & & $\begin{array}{c}\text { Urban } \\
\text { n (3111) }\end{array}$ & $\begin{array}{c}\text { Rural } \\
\text { n (1213) }\end{array}$ & & \\
\hline \multicolumn{6}{|l|}{ Gender } \\
\hline Men & 567 & 1677 & 742 & 2986 & $(55.0)$ \\
\hline Women & 498 & 1434 & 471 & 2403 & $(45.0)$ \\
\hline \multicolumn{6}{|l|}{ Age (years) } \\
\hline Mean \pm SD & $18.9 \pm 2.7$ & $18.6 \pm 2.6$ & $18.1 \pm 2.6$ & & \\
\hline \multicolumn{6}{|l|}{ Age category (years) } \\
\hline $15-18$ & 501 & 1651 & 756 & 2908 & $(54.0)$ \\
\hline $19-24$ & 564 & 1460 & 457 & 2481 & $(46.0)$ \\
\hline \multicolumn{6}{|l|}{ Q1401 } \\
\hline \multicolumn{6}{|c|}{ Age at intended marriage (years) } \\
\hline Men (median/min-max) & $25(18-38)$ & $25(19-35)$ & $25(20-37)$ & & \\
\hline Women (median/min-max) & $24(18-30)$ & $24(17-30)$ & $23(17-30)$ & & \\
\hline \multicolumn{6}{|l|}{ Education } \\
\hline None & 0 & 15 & 0 & 15 & $(0.3)$ \\
\hline Primary & 60 & 155 & 107 & 322 & $(6.0)$ \\
\hline Junior High & 127 & 440 & $390^{\mathrm{c}}$ & 957 & $(18.0)$ \\
\hline Senior High & $647^{\mathrm{a}}$ & $1971^{\mathrm{a}}$ & $624^{a}$ & 3242 & $(60.0)^{\mathrm{a}}$ \\
\hline Academy/University & $231^{b}$ & $530^{b}$ & 92 & 853 & $(16.0)$ \\
\hline \multicolumn{6}{|l|}{ Wealth index* } \\
\hline Very poor & 26 & 160 & $185^{\mathrm{d}}$ & 371 & $(7.0)$ \\
\hline Poor & 85 & 375 & $352^{d}$ & 812 & $(15.0)$ \\
\hline Middle & $146^{\mathrm{e}}$ & $676^{\mathrm{e}}$ & $308^{d}$ & 1130 & $(21.0)$ \\
\hline Rich & $305^{\mathrm{e}}$ & $837^{\mathrm{e}}$ & 220 & 1362 & $(25.0)$ \\
\hline Very rich & $503^{\mathrm{e}}$ & $1063^{\mathrm{e}}$ & 148 & 1714 & $(32.0)$ \\
\hline \multicolumn{6}{|l|}{ Own mobile phone } \\
\hline Yes & 1000 & 2873 & 1070 & 4943 & $(92.0)$ \\
\hline No & 65 & 238 & 143 & 446 & $(8.0)$ \\
\hline \multicolumn{6}{|l|}{ Internet usage over last month } \\
\hline Yes & 1033 & 2962 & 1098 & 5093 & $(95.0)$ \\
\hline -Almost everyday & 953 & 2354 & 777 & 4084 & $(80.0)$ \\
\hline -At least once a week & 66 & 451 & 231 & 748 & $(15.0)$ \\
\hline -Less than once a week & 14 & 157 & 91 & 262 & $(5.0)$ \\
\hline No & 32 & 149 & 114 & 295 & $(5.0)$ \\
\hline
\end{tabular}

Notes: ${ }^{a}$ Senior High School was the most predominant educational level; ${ }^{b}$ Academy/University was the second highest educational level in urban areas; ${ }^{\mathrm{c}}$ Junior High School was the second highest educational level in rural areas; ${ }^{\mathrm{d}}$ combined wealth index was lower-middle class; ${ }^{\mathrm{e}}$ combined wealth index was upper-middle class. 


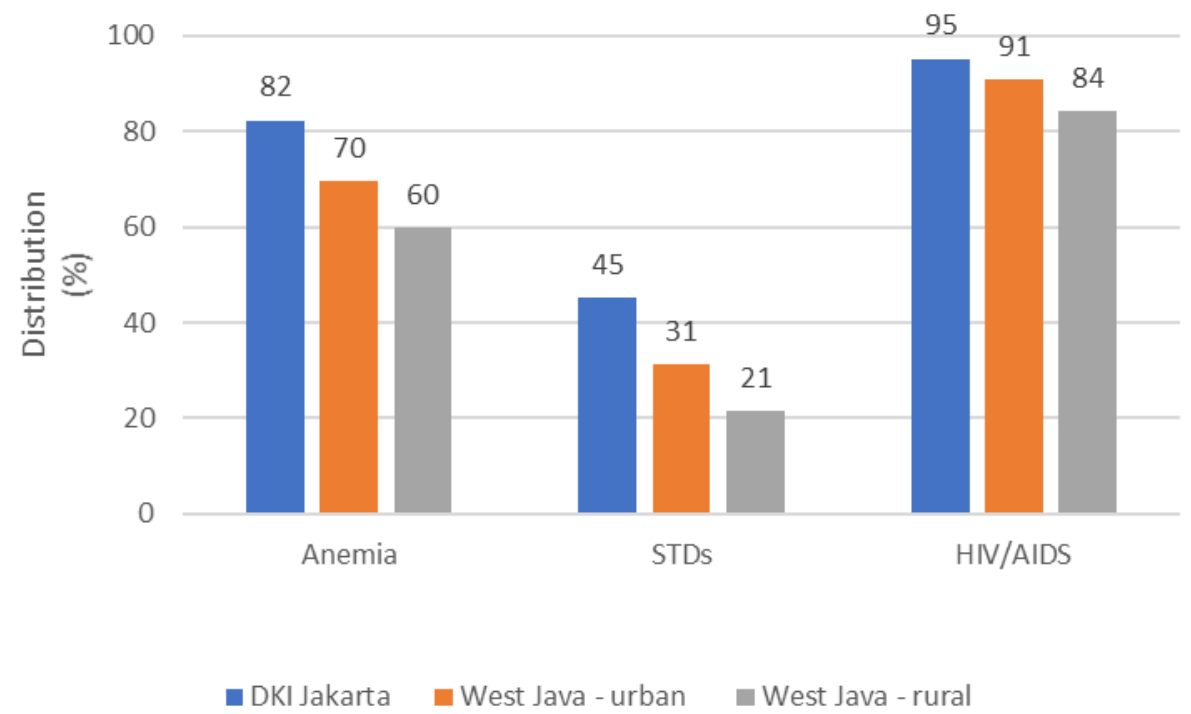

Figure 1. Distribution of unmarried adolescents and young adults in DKI Jakarta and West Java Province who had 'Ever Heard' about anemia, sexual transmitted diseases (STDs) and HIV/AIDS

Similar to anemia, STDs and HIV/AIDS had been significantly more heard of in Jakarta than in West Java ( $p=0.000$ ). Evenmore, HIV/AIDS had been significantly more heard in rural area of West Java, compared to the topic of anemia and STDs $(\mathrm{p}=0.000)$ in Jakarta.

The question on the definition of anemia was explored and this showed that anemia was generally known as a simple blood deficit. Of this knowledge the adolescents in Jakarta had the highest proportion among the respondents $(60 \%)$; as opposed to adolescents in West Java rural areas who did not know the definition of anemia (58\%) (Figure 2a). As for the cause of anemia, the most mentioned causes were lack of vegetables and fruit $(31 \%)$ as well as lack of meat/fish consumption (27\%) as depicted in Figure $2 \mathrm{~b}$. Again, two-thirds of the adolescents in West Java rural areas did not know the cause of anemia. As to whether anemia could be treated or prevented, taking a pill was predominantly mentioned by adolescents in Jakarta (53\%) and in West Java urban and rural areas by $37 \%$ and $28 \%$, respectively. Hence, they did not specifically mention iron tablets in particular. Taken together, both definition and cause of anemia were scored significantly better by respondents in Jakarta compared to urban and rural areas of West Java Province $(\mathrm{p}=0.000)$.
The knowledge of anemia was predominantly poor (69\%) in Jakarta and even poorer in West Java rural area (89\%) and the difference was significant $(\mathrm{p}=0.000)$. Similarly, the knowledge of sexually transmitted diseases (STDs) was predominantly poor in Jakarta (89\%) compared to West Java rural areas (98\%), the proportions being significantly different $(\mathrm{p}=$ 0.000 ). Interestingly, the knowledge about HIV/ AIDS was moderate $(32 \%)$ to good $(59 \%)$ in Jakarta. The knowledge distribution in DKI Jakarta was significantly better than in West Java $(p<0001)$, signifying that the knowledge in urban areas was better than in rural areas (Figure 3).

Some of the questions about HIV/AIDS were incorrectly answered, such as that the infection was spread by mosquitos and sharing of food (data not shown). The most frequent clinical symptoms known for genital infection in men were genital discharge and burning pain on urinating; whereas for genital infection in women the known symptoms were foul smelling discharge, genital discharge and also burning pain during urination.

\section{Source of information for health education among adolescents and young adults}

The most frequent health information source was the school. Interestingly, education on HIV/ 


\section{a}

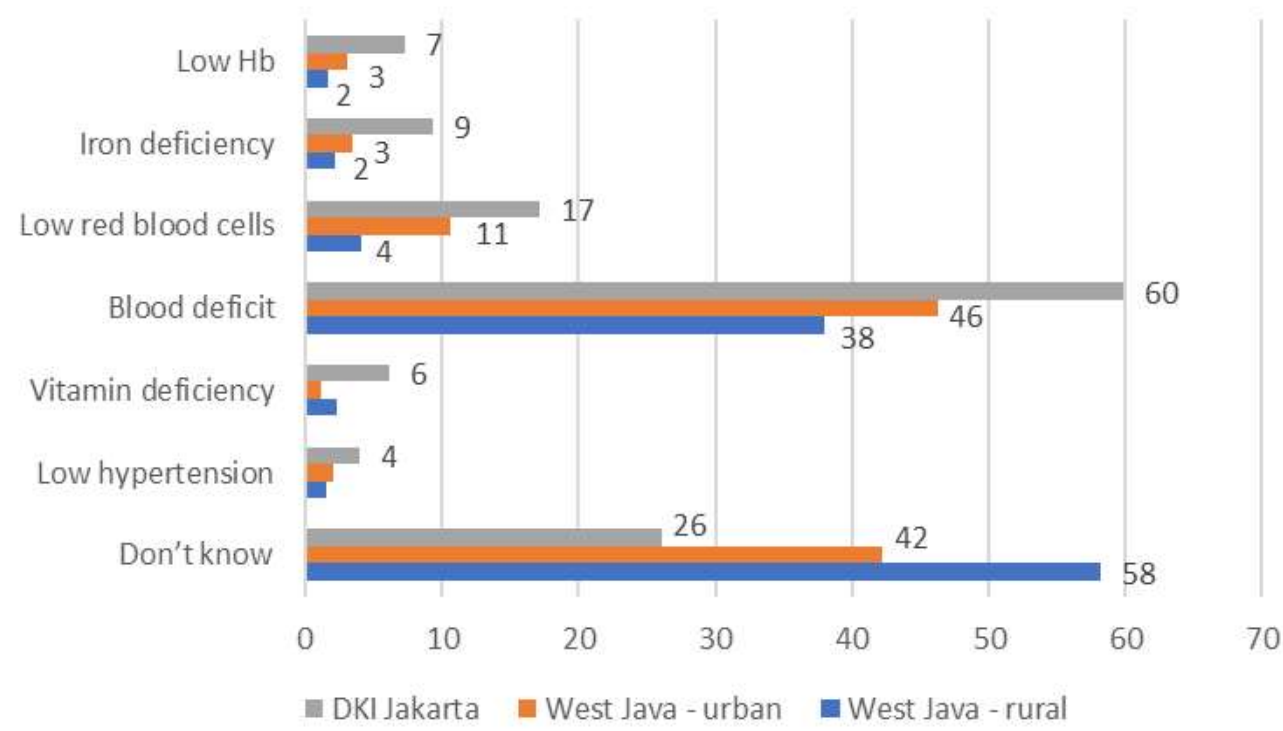

b

Lack consumption of vegetables/fruit

Lack consumption of meat/fish/liver

Malnutrition

Bleeding

Menstruation

Infection

Lack of sleep

Tired

Don't know
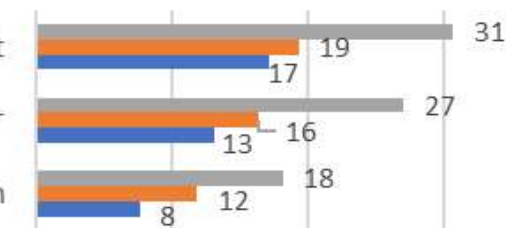

18
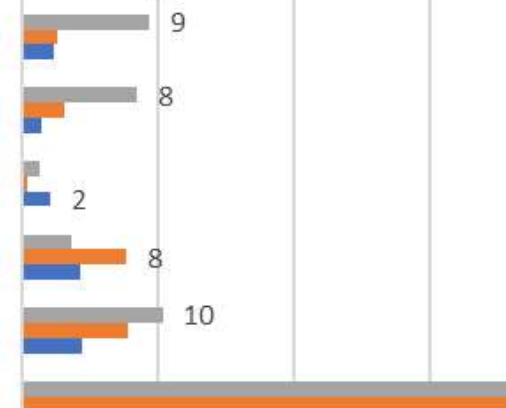

36
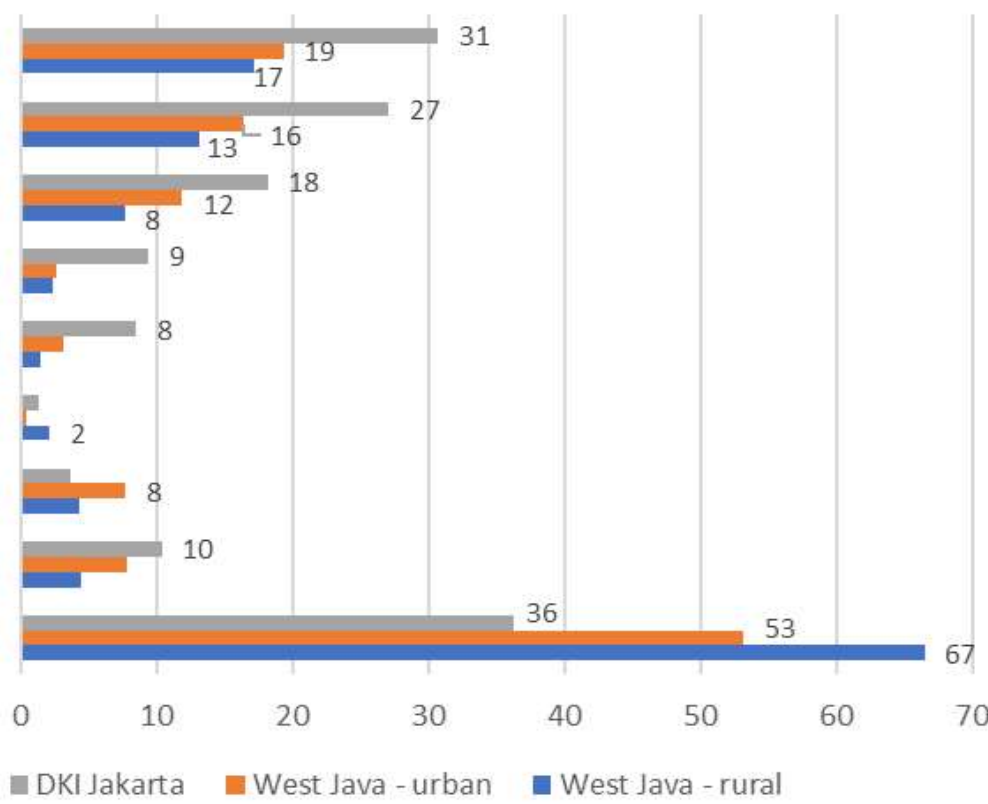

Figure 2. Distribution of (a) definition and (b) etiology of anemia according to unmarried adolescents aged 15-24 years in DKI Jakarta and West Java Province

AIDS (63\%) was significantly (p 0.000) more given compared to STDs (19\%). For HIV/AIDS, radio/TV was the second source of information (53\%) followed by information on internet (33\%), whereas information about STDs was more frequently gathered from friends $(11 \%)$ and the internet (9\%) (Figure 4). There was no question in SDKI 2017asking for the source of information about anemia that limited the analysis in comparing the source of information.

\section{DISCUSSION}

This study has explored the knowledge of HIV/AIDS, sexually transmitted diseases (STDs) and anemia among adolescents aged 15-24 years from two provinces in Indonesia, namely West Java and Jakarta, resulting in poor knowledge of anemia and STDs and moderate to good knowledge of HIV/AIDS. Interestingly, adolescents in Jakarta have heard significantly 


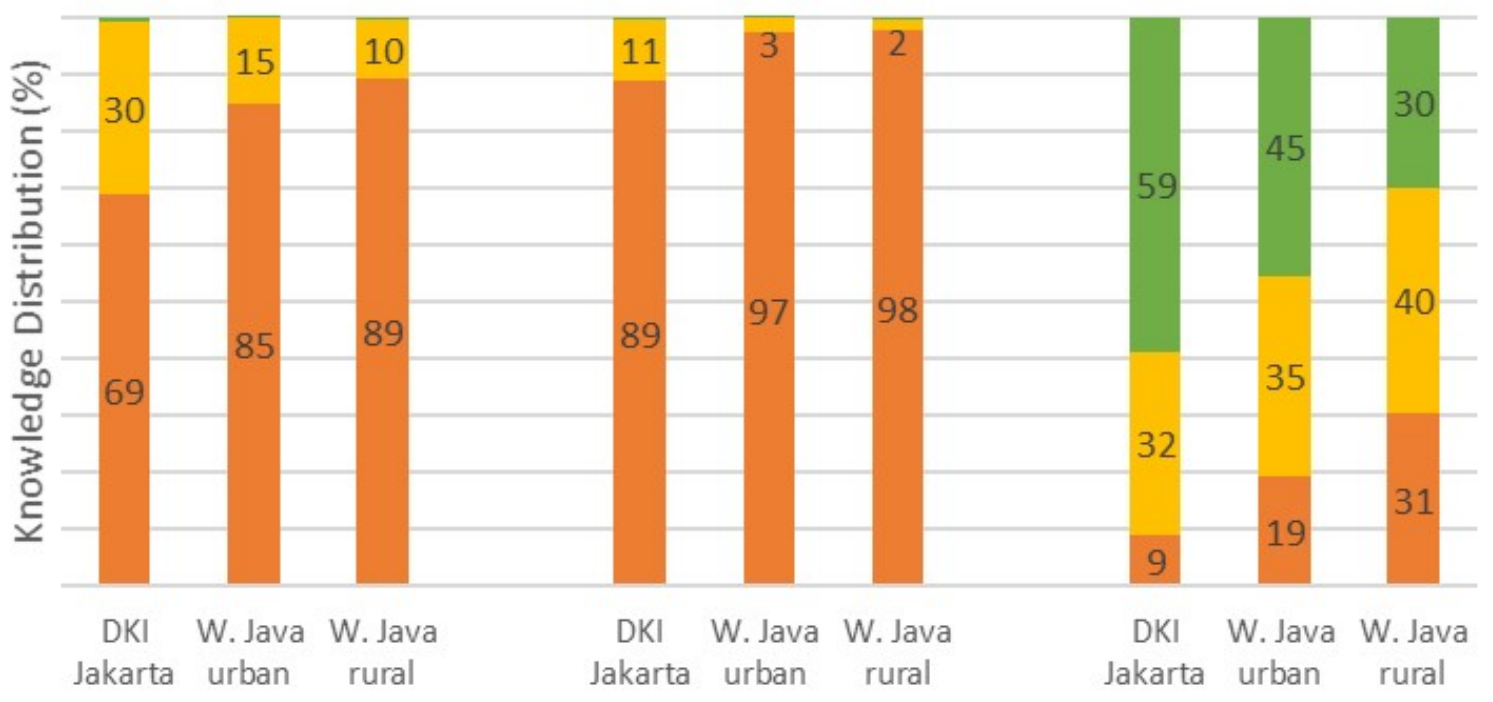

Anemia

STDs

HIV/ADIS

a Poor Moderate $\square$ Good

Figure 3. Knowledge of anemia, sexually transmitted diseases and HIV/AIDS among unmarried adolescents aged 15-24 years in DKI Jakarta and West Java Province

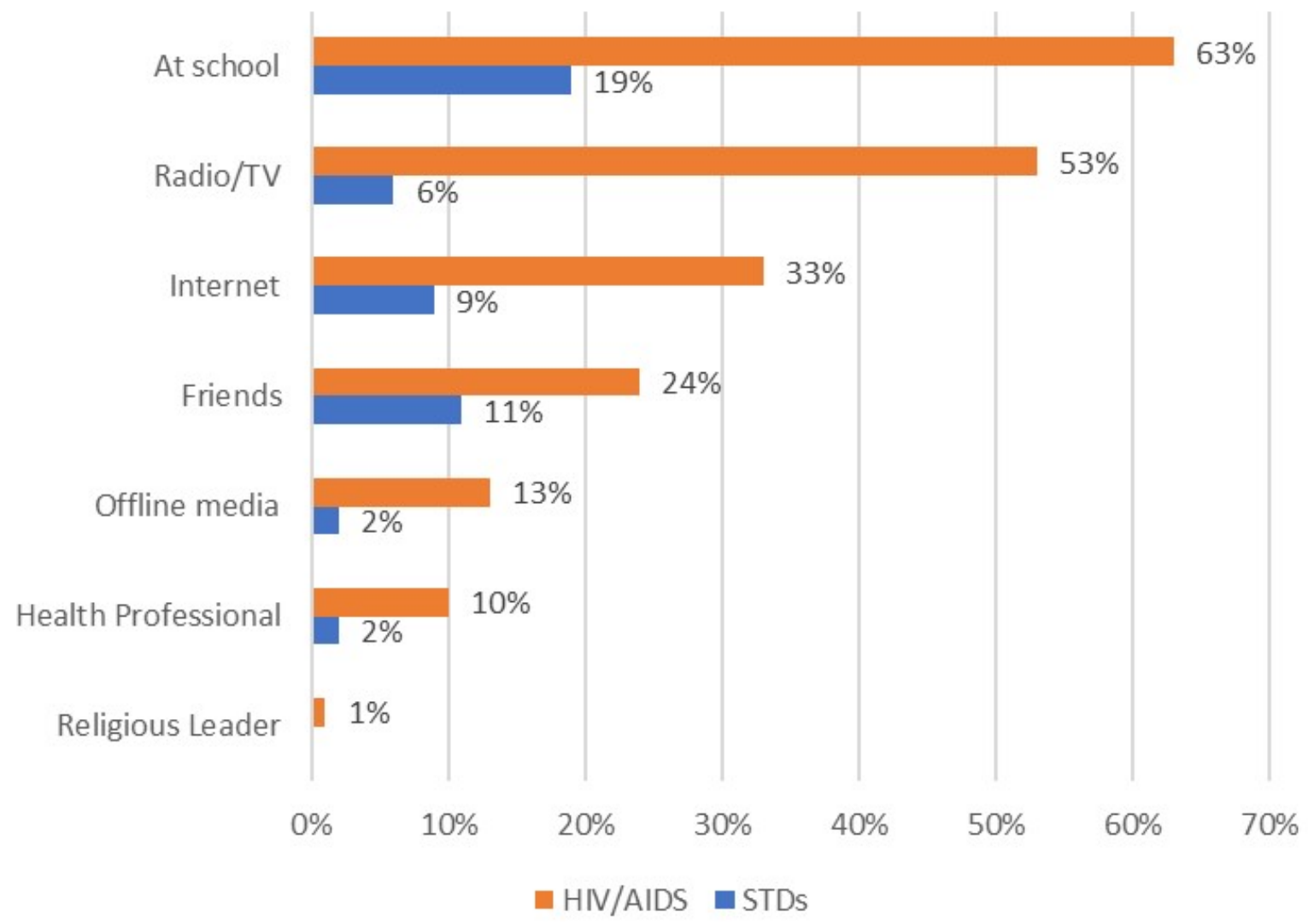

Figure 4. Sources of information about (a) sexual transmitted diseases and (b) HIV/AIDS 
more about those diseases compared to those residing in West Java, and those in urban areas have heard more than those in rural areas.

The disparities in reproductive health education across urban and rural areas may lead to inequities in awareness and utilization of health services. ${ }^{(15)}$ Interestingly, even though the wealth index in West Java rural area is lower-middle class, over $90 \%$ of adolescents have a mobile phone and almost daily internet access. It seems that the mobile phone has become an essential tool in the era of digitalization. The use of mobile phones for example on mobile health or mHealth application via text-messaging information, videos and other social media platforms plays a role, highlighting the significant opportunity to impact health behaviors globally, particularly in low-and middle-income countries. ${ }^{(16)}$ Hence, the choice to access information from various sources depends on the individual's interests and curiosity. Even though the internet seems to be essential nowadays in passing the information, radio and TV are also useful sources of information. A study in Uganda has shown that the frequency of access to information in traditional mass media such as $\mathrm{TV}$, radio, and print media is more successful in enhancing the knowledge about HIV among adolescents. ${ }^{(17)}$ Information about HIV/AIDS has been regularly broadcast via radio/TV as a campaign to prevent HIV/AIDS. The HIV/AIDS campaign program in Indonesia may have become a success story, causing knowledge about HIV/ AIDS to be predominantly moderate and good in Jakarta $(91.0 \%)$ and West Java $(70.0 \%)$. However, the optimal source of reproductive health education is still the school period. For example, the major source of information of STDs is the school. Yet, the knowledge of STDs is very poor. The STDs may be seen as a sensitive issue in the community. Our result has shown that the information about STDs has been gathered from friends and internet. Adolescents are prone to STDs because of the influence and pressure of their friends and the curiosity to experiment with sexual activity. Clearly, health promotion for STD prevention needs to be carefully well-designed with a good assessment based on social and behavioral as well as cultural determinants given by teachers and medical professionals in the school curricula. ${ }^{(18)}$ Interestingly, educational programs in Italy have been designed based on information needs and risk perceptions among adolescents and young adults, resulting in an effective intervention to improve knowledge about HIV and STDs. ${ }^{(10)}$ Therefore, schools have been proven to be a good place for providing information during the period of adolescence. ${ }^{(19)}$

Next to knowledge of STDs and HIV/ AIDS, knowledge of anemia plays a significant role among adolescents. The most common cause of anemia in developing countries is iron deficiency anemia. It seems that the young adults in our study had poor knowledge of anemia , although they have ever heard a lot about anemia. Blood deficit in general (48.0\%), lack of iron-containing vegetables or fruits $(22.0 \%)$ as well as lack of meat/fish consumption (18.0\%) have been mentioned as the cause of anemia. However, since there was no question in the questionnaire asking about the source of information about anemia, nutrition education at school for the students is imperative. An integrated school-based nutrition program with their mothers have resulted in a significant increase in the knowledge and attitude of the mothers in improving the nutritional status of their children. ${ }^{(20)}$ Indeed, in the developing countries, iron deficiency anemia is predominant, as a result of inadequate intake of micronutrientrich foods and the inadequate utilization of available micronutrients in the diet due to infections, and other dietary factors. Consumption of vitamin-A rich and iron-rich foods as well as micronutrient fortification in cooking salt are recommended for both women and children. ${ }^{(21)}$ The 1000 days of growth of the fetus into babies is essential. An anemic pregnant woman may deliver low birth weight babies, and children with stunted growth, ${ }^{(22)}$ therefore, knowledge of anemia should be introduced at a young age during lessons in reproductive health education. 
It is worth noting that next to iron deficiency anemia, hemoglobinopathies such as thalassemia minor or trait are another important etiology of anemia, ${ }^{(23)}$ especially in Indonesia and other countries located in the thalassemia belt area. ${ }^{(24)}$ Interestingly, thalassemia minor or trait is not well known among adolescents, and none of the respondents acknowledge thalassemia as the cause of anemia in their answer. Moreover, knowledge of thalassemia is not wide-spread among general practitioners. ${ }^{(25)}$ Thalassemia is inherited in an autosomal recessive manner, thus, when thalassemia carrier is married to another carrier, the probability of having a thalassemia major baby in every pregnancy is $25.0 \%$. ${ }^{(26)}$ With the magnitude of possibly around $6-10.0 \%$ thalassemia carriers in West Java, ${ }^{(8)}$ the topic of thalassemia needs to be added to the premarital course or education. Ideally, early detection for thalassemia carriers should be conducted in adolescents, integrated in the premarital program to plan their future partner. ${ }^{(27)}$

This study, however, has some limitations. Unlike the questions on knowledge about HIV/ AIDS which are true/false questions, the questions on knowledge about anemia and STDs are more based on what the respondents know in open questions mode. Another limitation is that there are no questions in IDHS 2017 about the source of information for anemia. A validated and reliable questionnaire about the knowledge of anemia as well as the source of information needs to be further developed.

\section{CONCLUSION}

The knowledge of anemia and sexually transmitted diseases among unmarried adolescents from Jakarta and West Java is poor, whereas knowledge of HIV/AIDS is moderate to good. Poor knowledge of anemia is a challenge in introducing thalassemia, an autosomal recessive inherited hemoglobinopathy. Since Indonesia is harboring $6-10.0 \%$ thalassemia carriers, a holistic approach to premarital education programs in schools is beneficial in enhancing the knowledge of sexual and reproductive health for a better family planning to achieve the next golden generation.

\section{CONFLICT OF INTEREST}

The authors declare that there are no competing interests.

\section{ACKNOWLEDGEMENT}

This study has been financially supported by the Competitive Grant from the National Population and Family Planning Board, Indonesia (BKKBN) for the year 2020. The authors declare that the results of this study are not affected by the grantor. We are grateful to Indra Murty Surbakti and Besral for critical review and fruitful discussion. We thank Heru for his support in the study.

\section{CONTRIBUTORS}

ES, RP conceived the study, developed the idea, participated in the design; MBR retrieved and verified data. ES, MBR, EP, RP analyzed the data and reviewed the manuscript. All authors contributed towards drafting and have agreed to be accountable for all aspects of the work; and all the authors read and approved the manuscript.

\section{DATA AVAILABLE STATEMENT}

Data is available upon request and permission from the National Population and Family Planning Board, Indonesia.

\section{REFERENCES}

1. Snow RC, Laski L, Mutumba M. Sexual and reproductive health: progress and outstanding needs. Glob Public Health 2015;10:149-73. doi: 10.1080/17441692.2014.986178.

2. Kementerian Kesehatan Republik Indonesia, Pusat Data dan Informasi. Infodatin HIV. Jakarta Selatan: Kementerian Kesehatan Republik Indonesia, Pusat Data dan Informasi;2020. 
3. World Health Organization. Regional Office for the Western Pacific Regional. Framework for the triple elimination of mother-to-child transmission of HIV, hepatitis B and syphilis in Asia and the Pacific, 2018-2030. Manila: World Health Organization Regional Office for the Western Pacific;2018.

4. World Health Organization. Anaemia. Geneva: World Health Organization; 2017.

5. Chaparro CM, Suchdev PS. Anemia epidemiology, pathophysiology, and etiology in low- and middle-income countries. Ann N Y Acad Sci 2019; 1450:15-31. doi: 10.1111/nyas.14092.

6. Di Renzo GC, Spano F, Giardina I, Brillo E, Clerici G, Roura LC. Iron deficiency anemia in pregnancy. Womens Health (Lond) 2015;11:891-900. doi: 10.2217/whe.15.35.

7. De Andrade Cairo RC, Rodrigues Silva L, Carneiro Bustani N, Ferreira Marques CD. Iron deficiency anemia in adolescents; a literature review. Nutr Hosp 2014;29:1240-9. doi: 10.3305/nh.2014.29.6. 7245 .

8. Kementerian Kesehatan Republik Indonesia. Direktorat Pencegahan dan Pengendalian Penyakit Tidak Menular. Pedoman pengendalian penyakit thalassemia di fasilitas kesehatan tingkat pertama. Jakarta: Kementerian Kesehatan Republik Indonesia; 2017.

9. Bakrania S, Ghimire A, Balvin N. Bridging the gap to understand effective interventions for adolescent well-being: an evidence gap map on protection, participation, and financial and material well-being in low and middle-income countries. UNICEF Office of Research - Innocenti, Florence. 2018.

10. von Rosen FT, von Rosen AJ, Riemenschneider FM, Damberg I, Tinnemann P. STI knowledge in Berlin adolescents. Int J Environ Res Public Health 2018;15: 110. doi: 10.3390/ijerph15010110.

11. Zizza A, Guido M, Recchia V, Grima P, Banchelli Tinelli A. Knowledge, information needs and risk perception about HIV and sexually transmitted diseases after an education intervention on Italian high school and university students. Int J Environ Res Public Health 2021:2069. https://doi.org/ 10.3390/ijerph18042069.

12. Badan Kependudukan dan Keluarga Berencana Nasional, Badan Pusat Statistik, Kementerian Kesehatan. Survei Demografi dan Kesehatan Indonesia 2017: Buku Remaja. September 2018. Jakarta: Badan Pusat Statistik; 2018.

13. Gubernur Propinsi Daerah Khusus Ibukota Jakarta. Peraturan Gubernur DKI-Jakarta no. 185 tahun 2017 tentang konseling dan pemeriksaan kesehatan bagi calon pengantin. Jakarta:
Gubernur Propinsi Daerah Khusus Ibukota Jakarta; 2017.

14. Inner City Fund (ICF). Demographic and health surveys: standard recode manual for DHS 7. The Demographic and Health Surveys Program. Rockville, Maryland, USA: ICF; 2018.

15. Ilori OR, Awodutire PO, Ilori OS. Awareness and utilization of adolescent reproductive health services among in-school adolescents in urban and rural communities in Oyo State. Niger Med J 2020;61:67-72. doi: 10.4103/nmj. NMJ_38_19.

16. Källander K, Tibenderana JK, Akpogheneta OJ, et al. Mobile health (mHealth) approaches and lessons for increased performance and retention of community health workers in low- and middleincome countries: a review. J Med Internet Res 2013;15:e17. doi: 10.2196/jmir.2130.

17. Bago JL, Lompo ML. Exploringthe linkage between exposure to mass media and HIV awareness among adolescents in Uganda. Sex Reprod Health 2019;21:1-8. doi: 10.1016/ j.srhc.2019.04.004.

18. Borawski EA, Tufts KA, Trapl ES, Hayman LL, Yoder LD, Lovegreen LD. Effectiveness of health education teachers and school nurses teaching sexually transmitted infections/human immunodeficiency virus prevention knowledge and skills in high school. J Sch Health 2015;85:18996. doi:10.1111/josh.12234.

19. Mason-Jones AJ, Sinclair D, Mathews C, Kagee A, Hillman A, Lombard C. School-based interventions for preventing HIV, sexually transmitted infections, and pregnancy in adolescents. Cochrane Database Syst Rev 2016; 11:CD006417. doi: 10.1002/14651858.CD006417. pub3.

20. Angeles-Agdeppa I, Monville-Oro E, Gonsalves JF, Capanzana MV. Integrated school based nutrition programme improved the knowledge of mother and schoolchildren. Matern Child Nutr 2019;15 Suppl 3:e12794. doi: 10.1111/mcn.12794.

21. Beluska-Turkan K, Korczak R, Hartell B, et. al. Nutritional gaps and supplementation in the first 1000 days. Nutrients 2019;11:2891. doi: 10.3390/nu11122891.

22. Rahman MM, Abe SK, Rahman MS, et. al. Maternal anemia and risk of adverse birth and health outcomes in low- and middle-income countries: systematic review and meta-analysis. Am J Clin Nutr 2016;103:495-504. doi: 10.3945/ ajcn.115.107896.

23. Hoffmann JJ, Urrechaga E, Aguirre U. Discriminant indices for distinguishing thalassemia and iron deficiency in patients with 
microcytic anemia: a meta-analysis. Clin Chem Lab Med 2015;53:1883-94. doi: 10.1515/cclm-20150179 .

24. Fucharoen S, Winichagoon P. Haemoglobinopathies in southeast Asia. Indian J Med Res 2011;134:498-506.

25. Sahiratmadja E, Wijaya MA, Widjajakusuma A, Maskoen AM, Dewanto JB, Panigoro R. The knowledge about thalassemia among medical students and general practitioners in Bandung and the prevalence of $\alpha$-thalassemia carrier. J Indon Med Assoc 2020;70:48-58. doi: 10.47830/ jinma-vol.70.4-2020-232.
26. Kohne E. Hemoglobinopathies: clinical manifestations, diagnosis, and treatment. Dtsch Arztebl Int 2011;108:532-40. doi: 10.3238/ arztebl.2011.0532.

27. Amato A, Cappabianca MP, Lerone M, et al. Carrier screening for inherited haemoglobin disorders among secondary school students and young adults in Latium, Italy. J Community Genet 2014;5:265-8. doi: 10.1007/s12687-0130171-z. 